\title{
Examining the Impact of Talent Management on Organizational Trust and Employee Retention
}

\author{
Mubashir Majid Baba \\ Research Scholar, Department of Management Studies, University of Kashmir, J\&K, India \\ E-Mail: mubashirbaba@rediffmail.com
}

\begin{abstract}
Talent management aims at improving the potential of employees who are seen as being able to make a valuable difference for the organization, now or in the future. In other words it deals with attracting, developing and retaining the key organizational talent. In this research, the relationship between talent management, organizational trust, and employee retention is investigated among staff members of 4 Universities under study. The research method is explorative cum descriptive in nature. The statistical population consists of staff members of University of Kashmir, University of Jammu, Central University of Kashmir and Central University of Jammu. The sample included 261 employees, which were selected randomly. Data has been collected by a researcherdeveloped questionnaire. The results of hypothesis testing indicate that there is a significant relationship between talent management, organizational trust, and employee retention. The study is significant in that it draws attention to the effects of talent management on organizational trust and employee retention in organizations.
\end{abstract}

Keywords: Talent Management, Organizational Trust, Employee Retention, Human Resource, Education

\section{INTRODUCTION}

Talent is an instinctive quality possessed by few people, who have the capability to make a significant difference to current and future company performance, which is equal to competencies of a person that needs to be explored for the competitive advantage of the organization. The modern organizations realized that their success is dependent on how they are able to attract, develop and retain the right talent for the organization that enable them to be successful in the competitive business environment. It is very much required to proactively anticipate and meet the demands of talent to meet the goals of the organization. Talent Management is a set of strategies and systems to increase productivity by developing improved processes for attracting, developing, retaining and utilizing people with the required skills and aptitude to meet current and future business needs. Talent management ensures organizations that right people with fit skills located at right place to access business strategy. Stockley (2007) states that the talent management is a very conscious, deliberate approach adopted by the organization to attract develop and retain people who possess right competencies, attitude and aptitudes to meet the strategic objectives of the organization. It focuses on people who got the right potential for achieving high performance levels. The labor market has entered a new era as a result of innovation, knowledge development, globalization and increased competition (Sheehan, 2012). On the other hand, the costs of recruiting employees, and low retention of experted employees, are major expenses for any organization. The success of organizations depends on employee retention which helps the organization in reducing employees turnover intention and enhancing organizational efficiency (Mohsen and Rasheed, 2007). So, organizations pay more attention on retention and attraction rather than recruitments and selection to survive in competitive environment (Holland et al., 2007) and talent management plays an important role in this process.

This paper attempts to explain the relationship among talent management, organizational trust and employee retention. When organizations are able to attract, develop and retain talented employees then organization will be able to achieve employee engagement, retention and value addition for the success of the organization.

\section{REVIEW OF LITERATURE}

\section{A. Talent Management (TM)}

Talent management is a professional term that gained popularity in the late 1990s. Talent management implies recognizing a person's inherent skills, traits, personality and offering him a matching job. Every person has a unique talent that suits a particular job profile and any other position will cause discomfort. It is the job of the Management, particularly the HR Department, to place candidates with prudence and caution. A wrong fit will result in further hiring, re-training and other wasteful activities. Talent management is a term that emerged in the 1990s to incorporate developments in Human Resources Management which placed more of an emphasis on the management of human resources or talent. The term was coined by David Watkins of Softscape in 1998. According to Hartley (2004), Talent Management is a term that extends over a wide set of activities, such as succession planning, employees loyalty, employees trust, human resource planning, employee performance management etc. Talent management is defined as a systematic and dynamic process of discovering, developing and sustaining talent. Schweyer (2004) argues that a very essential part of the TM strategy is to retain and develop the talent individuals. The six 
dimensions of talent management as given by Kull and Brandt (2007) are as follows:

Succession Planning: The systematic process of determining critical roles within the company, identifying and assessing possible successors, and providing them with the appropriate skills and experience for present and future roles.

Job Experience: It is identified that people need challenges and experiences to grow, and this is especially true for highpotential employees.

Training: Management development can be enhanced by foundational managerial education and high-impact leadership development.

Coaching: Employees need knowledge of their strengths and consequently the areas where they can improve to be able to develop in the best possible manner.

Mentoring: A manager builds self-esteem in the highpotential employee by offering praise, encouragement and support by believing in the employee's ability to achieve above everyone's expectations.

Career Management: Where the individual's career choices and development is in focus instead of what position to be filled.

\section{B. Organisational Trust}

Tschannen-Moran and Hoy (2000) reviewed articles on trust which were written over four decades before the turn of the millennium. They concluded that trust was a difficult concept to define, as it was complex and multifaceted and had different bases and degrees, depending on the context of the trust relationship. Bussing (2002) supports this view by stating that trust is "not at all a straightforward and clearly defined concept".

Trust can be regarded as a multidimensional construct, consisting of a cognitive (belief about another's trustworthiness), affective (role of emotions in the trust process) and behavioural (relying on another and disclosing sensitive information) base (Bussing, 2002; Gillespie \& Mann, 2004; Rousseau et al., 1998; Schoorman et al., 2007; Tschannen-Moran \& Hoy, 2000). Tschannen-Moran and Hoy (2000) consequently proposed a multidimensional definition of trust, namely:

Trust is one party's willingness to be vulnerable to another party based on the confidence that the latter party is (a) benevolent, (b) reliable, (c) competent, (d) honest, and (e) open.Despite the differences in conceptualisation, there are a number of common elements unifying the many different definitions of trust. In particular, there seems to be an agreement that trust is "the willingness to be vulnerable based on the positive expectations of the intentions or behaviour of others" (Mayer et al., 1995). Secondly, it seems that interdependence and uncertainty are necessary conditions for trust to develop. McEvily et al. (2006) conceptualise trust as a "choice to make oneself vulnerable under the conditions of interdependence and uncertainty".

For the purposes of this research study, organisational trust is defined as 'the choice to make oneself vulnerable with the express belief in the positive intent and commitment to the mutual gain of all parties involved in the relationship'.

According to various authors (Bews \& Martins, 2002; Hay, 2002; Lamsa \& Pucetaite, 2006; Martins, 2000; Nooteboom, 2002; Rossouw \& Van Vuuren, 2004; Schoorman et al., 2007; Whitener, 1997), three common characteristics of trust can be distinguished:

Trust in another party reflects a belief that the other party will act benevolently. Trust involves a willingness to be vulnerable and to risk the possibility that the other party may not fulfill the expectation of benevolent behaviour.

Trust involves dependence between the parties, meaning their performance is influenced by one another. Shaw (1997) postulates that trust influences performance within organisations on four levels:

Organisational success: trust is required to empower employees and groups to act on various objectives.

Group effectiveness: in order to realise a common goal, groups depend on the interdependency of people to work together. High levels of trust are needed for advanced performance.

One-on-one collaboration: people who work together need to trust one another. This enables information-sharing, taking necessary risks and dealing effectively with adversity.

Individual credibility: trust in employees is required for people to perform their jobs and will influence the degree to which people are given autonomy, resources and support. Support is usually given to people believed to be trustworthy.

\section{Employee Retention}

Employee retention is commonly considered to mean the ability to maintain a stable human resource. It is often linked to spirit and to organizational trust. Retention is a complex concept and there is no single recipe for keeping employees with a company (Sinha \& Sinha, 2012). Employee retention can also refer to the outcome of how many are retained per year. Lee and Mitchell (1994) support this belief and are talking about the concept of employee retention. Employee retention refers to all those efforts, done by the organization, which increases the chances for an employee to stay in the organization for a longer time. 
High employee turnover in addition to shortage of labor and an increasing business sector calls for employee retention.

A study concluded that for retaining good talented work force the organization has to create a positive environment for conducive working (Chaminade, 2007). Samuel (2008) analyzed that good and successful organizations do respect their employees and try to make policies more flexible for betterment of employees so that level of employee engagement can be achieved. Chiboiwa et al.(2010) found that retention is the process in which employer takes steps to prevent the job switching of their key employees. Another study describes that retention is an effort by which an employer make some good policies to retain talented employees for achieve the organization goals and success (Frank et al., 2004).

A study concluded that talented work force has high worth to the organizations due their expertise over the knowledge, their skills \& experience (Ejiofor \& Mbachu, 2001). On the other hand, Nwokocha \& Iherirohanma (2012) stated that organization treats them as an assets. Most of the previous studies agreed upon that good retention strategies leads to greater time span in the organization and also motivates them to do their job dedicatedly. There are various factors that affect employee retention. Some of them are training \& development, compensation, organizational culture, leadership, feedback.

\section{Relationship among variables under study}

Retaining talented employees is the priority of many organizations and it is the key differentiator of human capital management. Major companies today are facing the challenge of retaining their talent in the global markets (Scullion et al., 2010; Tarique \& Schuler, 2010).75\% of Chief Executive Officers agree that managing the organizational talent is their key priority (CIPD, 2010). People, intellectual capital and talent are ever more critical to organizational strategic success (Frank \& Taylor, 2004). Talented employees leave the organization if they are not satisfied with the total rewards, leadership and organizational policies etc. These problems occur when proper talent management practices are not in place (Griffeth \& Hom, 2001).

In the current competitive business environment, retention of highly talented employees is very important (Smith, 2009) as they contribute positively in improving the organizational productivity. Turnover reduction of these positions is important for organizational success, there is also view that improving employee turnover reduction beyond certain point will lead to diminishing marginal returns (Boudreau \& Ramstad, 2007).

Dissatisfaction with the job is the main reason for the individuals turnover decision. In spite of many endeavors by the organization to retain its talent, many employees leave their jobs. Some turnovers are unavoidable. Organizations always try to manage low job satisfaction, poor supervision or pay issues to make sure there are no avoidable turnovers. Research also revealed that decline in employee turnover rates are related to sales growth and improved employee morale. High standard HR practices contribute to company's profitability and market value and decreasing employee turnover rates (Batt, 2002). Organizational performance has negative impact on employee turnover (Shaw et al., 2005). Pay levels and employee satisfaction are important predictors of individual turnovers (Griffeth et al., 2000). Altinoz et al. (2013) considered effects of talent management on organizational trust in Ankara hotels and revealed that changing mid-range and senior hotel executives perceptions of talent management in a positive way will have a positive impact on trust in the organization.

\section{RESEARCH MODEL}

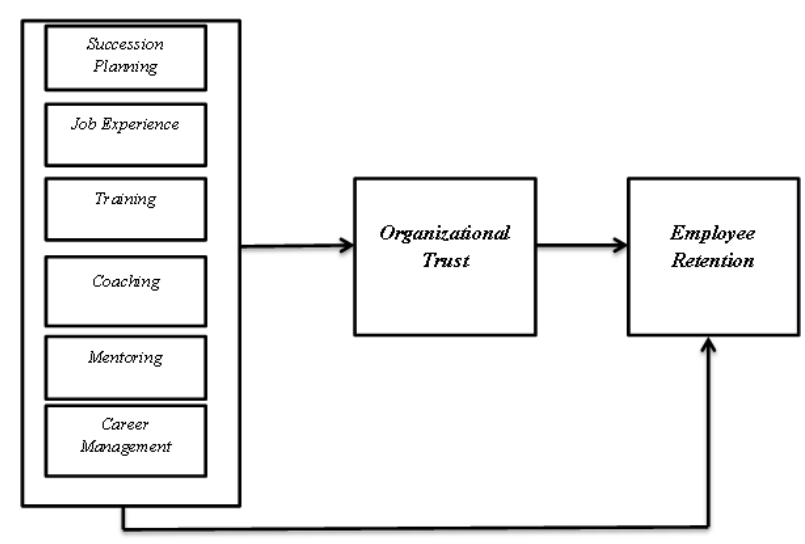

Fig. 1 Conceptual Model

\section{OBJECTIVES}

1. To study the perception level of employees towards the talent management, organizational trust and employee retention in the sample study organizations.

2. To examine impact of talent management on organisational trust among the employees under study.

3. To examine impact of talent management on employee retention among the employees under study.

4. To examine impact of organisational trust on employee retention among the employees under study.

\section{HYPOTHESES}

$\mathrm{H}_{1^{-}}$Talent management is positively and significantly associated with organizational trust.

$\mathrm{H}_{2^{-}}$Talent management is positively and significantly associated with employee retention.

$\mathrm{H}_{3}$ - Organizational trust is positively and significantly associated with employee retention.

\section{RESEARCH METHODOLOGY}

The current research is explorative cum descriptive in nature. The subjects are chosen among the employees in 4 universities of J\&K i.e. University of Kashmir, University of Jammu, Central University of Kashmir and Central 
University of Jammu (two central universities ad two old state universities). Data collection was done through random sampling. The sample of 261 was randomly selected based on the basis of Krejcie-Morgan (1970) table. In this study, questionnaire was used as a data collection tool. Questionnaire was framed according to the context of the study by the researcher keeping in view the studies conducted on the variables under study in the past.

Talent management questionnaire comprised of 20 items, organisational trust comprised of 10 items and employee retention comprised of 6 items. The validity of its content was ensured by using the expert viewpoints and consensus. The internal reliability of the items was verified by computing the Cronbach's alpha. The Cronbach alpha estimated for talent management was 0.873 , for organizational trust was 0.846 and for employee retention was 0.921 (table I). As the Cronbach's alpha in this research were all much higher 0.6 (Nunnally, 1978), the constructs were therefore deemed to have adequate reliability.

TABLE I RELIABILITY COEFFICIENT OF RESEARCH VARIABLES RELATED TO GIVEN HYPOTHESES

\begin{tabular}{|l|c|c|}
\hline \multicolumn{1}{|c|}{ Feature } & $\begin{array}{c}\text { Number of } \\
\text { Questions }\end{array}$ & $\begin{array}{c}\text { Cronbach's } \\
\text { Alpha Coefficient }\end{array}$ \\
\hline Talent Management & 20 & 0.873 \\
\hline Organizational Trust & 10 & 0.846 \\
\hline Employee Retention & 6 & 0.921 \\
\hline Succession Planning & 5 & 0.785 \\
\hline Job Experience & 3 & 0.871 \\
\hline Training & 3 & 0.820 \\
\hline Coaching & 3 & 0.831 \\
\hline Mentoring & 3 & 0.853 \\
\hline Career Management & 3 & 0.864 \\
\hline Total Participation & 36 & 0.917 \\
\hline
\end{tabular}

Source: Data compilation by the scholar for the present study

\section{A. Descriptive Data}

\section{FINDINGS}

TABLE II SAMPLE CHARACTERISTICS

\begin{tabular}{|c|c|c|c|}
\hline \multirow{2}{*}{$\begin{array}{c}\text { Demographic } \\
\text { Variable }\end{array}$} & \multicolumn{3}{|c|}{ Overall } \\
\cline { 2 - 4 } & Particulars & Frequency & \%age \\
\hline \multirow{3}{*}{ Gender } & Male & 153 & 58.62 \\
\cline { 2 - 4 } & Female & 108 & 41.37 \\
\hline \multirow{3}{*}{ Age } & $25-35$ years & 66 & 25.28 \\
\cline { 2 - 4 } & $35-45$ years & 103 & 39.46 \\
\cline { 2 - 4 } & $45 \&$ above & 92 & 35.24 \\
\hline
\end{tabular}

Source: Data compilation by the scholar for the present study

This study attempts to understand the relationships among talent management, organizational trust, and employee retention. The social demographic qualification of the participants are as follows: 153 male employees (58.62\%) and 108 female employees (41.37\%). The maximum number of employees were observed in the age group 35-45 years with 39.46 percent (frequency 103) followed by 34.24 percent of the respondents (frequency 92) in 45 \& above years age group, and 25.28 percent (frequency 66) in the age group 25-35 years respectively (table II).

In the table III, mean and standard deviation for each of the variables in research variables was also examined. A mean score of 3.96 or percentage score of $79.2 \%$ indicates that an above average level of talent management practices is perceived by faculty members in the sampled universities. The standard deviation of 0.79 also supports that the results are reasonably trustworthy. It was also found that the mean score of organizational trust to be 3.85 or percentage score of $77.0 \%$ indicating that an above average level of organizational trust is perceived by faculty members. Further the mean score for employee retention also came to be more than the average level (3.87) with the percentage mean score of $77.4 \%$. Among the elements of talent management faculty members have shown higher satisfaction towards career management (4.44) followed by training (3.97), coaching (3.92), employee retention (3.87), mentoring (3.83), job- experience (3.82) and succession planning (3.78).

In the present study, the pearson correlation was also utilized to examine whether or not a linear relationship existed between talent management, organizational trust and employee retention among the staff members under study. As is indicated from the table 4, perception of staff members regarding their talent management is positively, strongly and significantly correlated $(\mathrm{r}=.494 ; \mathrm{p}<.01)$ with their organisational trust. The perception of faculty members regarding their organisational trust is also positively, strongly and significantly correlated $(\mathrm{r}=.415$; $\mathrm{p}<.01)$ with the employee retention. This indicates that more the trust of staff members regarding their organisation, better are the chances to retain those employees (table 4). Also the relationship obtained from table 4 shows a significant relationship between talent management and employee retention. Pearson correlation coefficient between talent management and employee retention $(r=.367)$ is significant at level $\mathrm{p}<.01$.

TABLE III MEANS AND STANDARD DEVIATIONS

\begin{tabular}{|l|c|c|c|}
\hline \multicolumn{1}{|c|}{ Variable } & Mean & $\begin{array}{c}\text { Percentage of } \\
\text { Mean score }\end{array}$ & $\begin{array}{c}\text { Standard } \\
\text { Deviation }\end{array}$ \\
\hline Talent Management & 3.96 & 79.2 & .79 \\
\hline Organizational Trust & 3.85 & 77.0 & .67 \\
\hline Employee Retention & 3.87 & 77.4 & .87 \\
\hline Succession Planning & 3.78 & 75.6 & .81 \\
\hline Job Experience & 3.82 & 76.4 & .87 \\
\hline Training & 3.97 & 79.4 & .71 \\
\hline Coaching & 3.92 & 78.4 & .79 \\
\hline Mentoring & 3.83 & 76.6 & .86 \\
\hline Career Management & 4.44 & 88.8 & .93 \\
\hline \multicolumn{2}{|c|}{ Source: Data compilation by the scholar for the present study }
\end{tabular}


TABLE IV CORRELATION BETWEEN RESEARCH VARIABLES UNDER STUDY

\begin{tabular}{|c|c|c|c|c|c|c|c|c|c|c|}
\hline S. No. & Variables & 1 & 2 & 3 & 4 & 5 & 6 & 7 & 8 & 9 \\
\hline 1 & Talent Management & 1 & & & & & & & & \\
\hline 2 & Organizational Trust & $.494 * *$ & 1 & & & & & & & \\
\hline 3 & Employee Retention & $.367 * *$ & $.415 * *$ & 1 & & & & & & \\
\hline 4 & Succession Planning & $.673 * *$ & $.692 * *$ & $.347 * *$ & 1 & & & & & \\
\hline 5 & Job Experience & $.542 * *$ & $.564 * *$ & $.430 * *$ & $.259 * *$ & 1 & & & & \\
\hline 6 & Training & $.873 * *$ & $.657 * *$ & $.547 * *$ & $.364 * *$ & $.688 * *$ & 1 & & & \\
\hline 7 & Coaching & $.610 * *$ & $.590 * *$ & $.469 * *$ & $.461 * *$ & $.552 * *$ & $.485^{* *}$ & 1 & & \\
\hline 8 & Mentoring & $.593 * *$ & $.490 * *$ & $.671 * *$ & $.692 * *$ & $.507 * *$ & $.560 * *$ & $.638 * *$ & 1 & \\
\hline 9 & Career Management & $.621 * *$ & $.463 * *$ & $.619 * *$ & $.541 * *$ & $.331 * *$ & $.391 * *$ & $.660 * *$ & $.561 * *$ & 1 \\
\hline
\end{tabular}

\section{B. Cause and Effect Relationships}

Due to a dearth of research evidence in the literature to establish the causal relationships between talent management, organizational trust and employee retention, the present study is aimed to examine the nature of causal linkages (if any) that exist among the three variables and also between their constituent elements. In the table 5 research Hypothesis was examined that include Beta and Sig. values. On the basis of these values Hypotheses were examined.

TABLE V IMPACT AMONG TALENT MANAGEMENT, ORGANIZATIONAL TRUST AND EMPLOYEE RETENTION

\begin{tabular}{|c|l|c|c|c|}
\hline No. & Independent Variable & Dependent Variable & Beta & Result \\
\hline 1. & Talent Management & Organisational trust & $.289^{*}$ & Supported \\
\hline 2. & Talent Management & Employee retention & $.328 * *$ & Supported \\
\hline 3. & Organisational trust & Employee retention & $.374 * *$ & Supported \\
\hline
\end{tabular}

Source: Data compilation by the scholar for the present study

Note: $* \mathrm{p}<.05 ; * * \mathrm{p}<.01$

The results given in table 5 clearly indicate that the organizational trust is significantly predicted by the talent management $(\beta=.289 ; p<.05)$. Also the results indicate that employee retention is significantly predicted by the talent management $(\beta=.328 ; p<.01)$. The results also revealed the significant impact of organizational trust on employee retention with beta value of .374 significant at .01 level. Further, the dimensions of the talent management (Succession Planning, Job Experience, Training, Coaching,
Mentoring, Career Management) also have a significant positive influence on organizational trust. Of the six dimensions in the talent management, training ( $\beta=.396 ; p<$ $.001)$ is the most influential predictor of organizational trust followed by job experience $(\beta=.347 ; p<.001)$, succession planning $(\beta=.261 ; p<.01)$, coaching $(\beta=.212 ; p<.01)$, mentoring $(\beta=.178 ; p<.05)$, and career management $(\beta=$ $.146 ; p<.05)$ (refer table 6$)$.

TABLE VI IMPACT OF TALENT MANAGEMENT (DIMENSION WISE) ON ORGANIZATIONAL TRUST

\begin{tabular}{|l|c|c|c|}
\hline Independent Variable & Dependent Variable & Beta & Result \\
\hline Succession Planning & Organisational trust & $.261^{* *}$ & Supported \\
\hline Job Experience & Organisational trust & $.347^{* * *}$ & Supported \\
\hline Training & Organisational trust & $.396^{* * *}$ & Supported \\
\hline Coaching & Organisational trust & $.212^{* *}$ & Supported \\
\hline Mentoring & Organisational trust & $.178^{*}$ & Supported \\
\hline Career Management & Organisational trust & $.146^{*}$ & Supported \\
\hline
\end{tabular}

Source: Data compilation by the scholar for the present study

Note: $* \mathrm{p}<.05 ; * * \mathrm{p}<.01 ; * * * \mathrm{p}<.001$

Also the dimensions of talent management (Succession Planning, Job Experience, Training, Coaching, Mentoring,
Career Management) were found to have significant positive influence on employee retention. Of the six 
dimensions in the talent management, job experience $(\beta=$ $.469 ; p<.001)$ is the most influential predictor of employee retention followed by mentoring $(\beta=.374 ; p<.001)$, training $(\beta=.271 ; p<.01)$, coaching $(\beta=.225 ; p<.01)$, career management $(\beta=.213 ; p<.05)$, and succession planning $(\beta=.186 ; p<.05)$.

TABLE VII IMPACT OF TALENT MANAGEMENT (DIMENSION WISE) ON EMPLOYEE RETENTION

\begin{tabular}{|l|c|c|c|}
\hline Independent Variable & Dependent Variable & Beta & Result \\
\hline Succession Planning & Employee retention & $.186^{*}$ & Supported \\
\hline Job Experience & Employee retention & $.469 * * *$ & Supported \\
\hline Training & Employee retention & $.271 * *$ & Supported \\
\hline Coaching & Employee retention & $.225^{* *}$ & Supported \\
\hline Mentoring & Employee retention & $.374 * * *$ & Supported \\
\hline Career Management & Employee retention & $.213^{*}$ & Supported \\
\hline \multicolumn{4}{|c|}{ Source: Data compilation by the scholar for the present study } \\
& \multicolumn{4}{|c}{ Note: $* .05 ; * * p<.01 ; * * p<.001$} \\
\hline
\end{tabular}

\section{DISCUSSION AND CONCLUSION}

The aim of this research was to determine the relationship between talent management, organizational trust, and employee retention. The most important findings of this study are that: a) talent management positively and significantly influences organizational trust b) talent management positively and significantly influences employee retention c) organizational trust positively and significantly influences employee turnover. Of the six dimensions in the talent management, training is the most influential predictor of organizational trust and career is least predictor of organizational trust. Further, among six dimensions in the talent management, job experience is the most influential predictor of employee retention and succession planning is the least predictor of employee retention.

The results also revealed that an above average level of talent management, organizational trust and employee retention is perceived by faculty members in the sampled universities. Higher educational institutions are the backbone of any society. It is this sector that provides skilled, qualified and competent human resource. Unfortunately, no Indian University is figuring in the list of top 100 Universities of the World. In this study an effort has been made to provide an insight that how the quality of Indian Universities can be improved with the help of talent management, organizational trust and employee retention. Based on the findings in the present research, it appears that many organizations, regardless of industry or size, could benefit from the increased formalization and integration of some human resource management strategies and policies that fall clearly within the talent management domain, including Career Management, Mentoring, Coaching, Training, Job Experience and Succession Planning. The managers have an important role to play in this regard, particularly with respect to understanding what motivates people, ensuring access to learning opportunities, and treating employee with respect which will ultimately lead to organizational trust and employee retention.
In the present study, the research approach and design used are based on previous related studies, but still few limitations have been observed. In the present study, the universities of $\mathrm{J} \& \mathrm{~K}$ were included to investigate the influence between the variables under study, including greater number of institutes from other regions as well in the future research could reveal more generalisable results. The study focused on higher education sector only. The scope of the research could be widened by including other sectors also. Further, the analysis suffers from sample size. Larger and representative sample is needed to further investigate the variables under study.

\section{REFERENCES}

[1] M.Altinoz, D. Çakıroglu and S. Çop, "Effects of talent management on organizational trust: A field study", Procedia-Social and Behavioral Sciences, Vol. 99, pp. 843-851, 2013.

[2] R.Batt, "Managing customer services: Human resource practices, quit rates, and sales growth", Academy of Management Journal, Vol. 45, pp. 587-597,2002.

[3] N.Bews and N. Martins, "An evaluation of facilitators of trustworthiness", SA Journal of Industrial Psychology/SA Tydskrif vir Bedryfsielkunde, Vol. 28, No. 4, pp. 14-19, 2002.

[4] J.W.Boudreau and P.Ramstad, Beyond HUMAN RESOURCE: The new science of human capital, Boston: Harvard Business School Press, 2007.

[5] Bussing, "Trust and its relations to commitment and involvement in work and organisations", SA Journal of Industrial Psychology/SA Tydskrif vir Bedryfsielkunde, Vol. 28, No.4, pp. 36-42, 2002.

[6] Chaminade, “A Retention Checklist: How Do You Rate?", 2007

[7] M.W.Chiboiwa, M.O.Samuel and C. Chipunza, "An Examination of Employee RetentionStrategy in a Private organization in Zimbabwe", African Journal of Business Management, Vol. 4, No.10, pp. 21032109, 2010.

[8] A.Chitsaz-Isfahani and H.R.Boustani, "Effects of talent management on employees retention: The mediate effect of organizational trust", International Journal of Academic Research in Economics and Management Sciences, Vol. 3, No. 5,pp. 114, 2014.

[9] CIPD.The war on talent?Talent management under human resource at in uncertain times. Available from Internet http://www.cipd.co.uk/, 2010.

[10] P.N.O. Ejiofor and A.U. Mbachu, "Imperative of Human Resource Practices in the NewMillennium", Journal of the Management Sciences, Vol. 5, No. 1, pp. 121-126, 2001.

[11] F.D.Frank, R.P.Finnegan and C.R.Taylor, "The Race for Talent: Retaining and Engaging Workers in the 21st Century", Human Resource Planning, Vol. 27, No. 3, pp. 12-25, 2004. 
[12] F.D.Frank and C.R.Taylor, "Talent Management: Trends that will shape the future", Human Resource Planning, Vol. 27, No. 1, pp. 3341, 2004.

[13] N.A.Gillespie and L.Mann, "Transformational leadership and shared values: The building blocks of trust", Journal of Managerial Psychology, Vol. 19, No. 6, pp. 588- 607, 2004.

[14] R.W.Griffeth and P.W. Hom, "Retaining valued employees. Thousand Oaks", CA: Sage,2001.

[15] R.W.Griffeth, P.W.Hom and S.Gaertner, "A meta-analysis of antecedents and correlates of employee turnover: Update, moderator tests, and research implications for the next millennium", Journal of Management, Vol. 26, pp. 463-488, 2000.

[16] D.Hartley, "Digital Beat. Training and Development", Vol. 58, No. 3, pp. 22-25, 2004

[17] A.Hay, "Trust and organisational change: An experience from manufacturing", SA Journal of Industrial Psychology, Vol. 28, No. 4, pp. 40-44, 2002. http://dx.doi.org/10.4102/sajip.v28i4.78 .

[18] P.Holland, C.Sheehan and H. De Cieri, "Attracting and retaining talent: Exploring human resources development trends in Australia", Human Resource Development International, Vol. 10, No. 3, pp. 247262, 2007

[19] R.V. Krejcie, University of Minnesota, Duluth; Daryle W. Morgan Texas A. \& M. University: Educational and Psychological Measurement, Vol. 30, pp. 607-610, 1970.

[20] P.Kull and E.Brandt, "Talent Management: How firms in Sweden find and nurture value adding human resources", Master's thesis within Business Administration, 2007.

[21] A.Lamsa and R.Pucetaite. Development of organisational trust among employees from a contextual perspective. Business Ethics: A European Review, 15(2), 130-141, 2006.

[22] T.W. Lee and T.R. Mitchell, "An alternative approach: The unfolding model of voluntary employee turnover", Academy of Management Review, Vol. 19, No. 1, pp. 51-89, 1994.

[23] N. Martins, "Developing a trust model for assisting management during change", SA Journal of Industrial Psychology/SA Tydskrif vir Bedryfsielkunde, Vol. 26, No. 3, pp. 27-31, 2000.

[24] R.C. Mayer, J.H. Davis and F.D.Schoorman. An integrative model of organisational trust. Academy of Management Review, 20, 709-734, 1995.

[25] B.McEvily, R.A.Weber, C.Bicchieri and V.T.Ho, "Can groups be trusted? An experimental study of trust in collective entities", In R. Bachmann \& A. Zaheer (Eds.), Handbook of trust research, pp. 5267, 2006. Cheltanham: Edward Elgar Publishing Limited.

[26] A.Mohammed, "The Impact of Talent Management on Employee Engagement, Retention and Value Addition in Achieving Organizational Performance", International Journal of Engineering and Management, Vol. 1, No. 12, pp. 142-152, 2016.

[27] M.Mohsen and N. Rashed, "Leadership From The Qur'an Relationship Between Taqwa, Trust And Business Leadership Effectiveness", (Doctoral dissertation, Universiti Sains Malaysia), 2007

[28] B.Nooteboom, "Trust: Forms, foundations, functions, failures and figures", Cheltanham: Edward Elgar Publishing Ltd, 2002.
[29] J.C.Nunnally, "Psychometric theory", (2nd ed.). New York: McGraw-Hill,1978.

[30] I.Nwokocha and B.J.E.Iherirohanma, "Emerging Trends in Employee Retention Strategiesin a Globalizing Economy: Nigeria in Focus", Asian Social Science, Vol. 8, No. 10, pp. 198-207, 2012.

[31] D. Rossouw and L. Van Vuuren, "Business ethics”, (3rd edn.). Cape Town: Oxford University Press South Africa, 2004.

[32] D.M.Rousseau, S.B.Sitkin, R.S.Burt, and C. Camerer, "Not so different after all: A cross discipline view of trust", Academy of Management Review, Vol. 23, No. 3, pp. 393-404, 1998.

[33] M.O. Samuel, "Using Motivational Strategy as Panacea for Employee Retention and Turnover in Selected Public and Private Sector Organizations in Eastern Cape Province of South Africa", Unpublished M.Sc. Thesis, University of Fort Hare, 2008.

[34] F.D.Schoorman, R.C.Mayer and J.H.Davis, "An integrative model of organisational trust: Past, present and future", Academy of Management Review, Vol. 32, No. 2, pp. 344-354, 2007.

[35] F.D.Schoorman, R.C. Mayer and J.H.Davis, "An integrative model of organisational trust: Past, present and future", Academy of Management Review, Vol. 32, No. 2, pp. 344-354, 2007.

[36] A.Schweyer, "The Talent Management System: best practices for recruitment, retention, and workforce planning. Toronto:Wiley", 2004

[37] H.Scullion and D.G.Collings. Global talent management. Journal of World Business, 45, 105 - 108, 2010.

[38] J.D.Shaw, N. Gupta and J.E. Delery, "Alternative conceptualizations of the relationship between voluntary turnover and organizational performance", Academy of Management Journal, Vol. 48, pp. 50-68, 2005 .

[39] R.B.Shaw. Trust in the balance. San Francisco: Jossy-Bass, 1997

[40] M. Sheehan, "Developing Managerial Talent: Exploring the Link between Management Talent and Perceived Performance in Multinational Corporations (MNCs)", European Journal Of Training And Development, Vol. 36, No. 1, pp. 66-85, 2012.

[41] C. Sinha and R.Sinha, "Factors Affecting Employee Retention: A Comparative Analysis of two Organizations from Heavy Engineering Industry", European Journal of Business and Management, Vol. 4, No. 3, pp. 145-162, 2012.

[42] R.C.Smith, "Greed is good", Wall Street Journal, 2009.

[43] D. Stockley, "Talent management concept-Definition and explanation", 2007.

[44] I.Tarique and R. Schuler, "Global talent management: Literature review, integrative framework, and suggestions for further research", Journal of World Business, Vol. 45, pp. 122 - 133, 2010.

[45] M.Tschannen-Moran and W.K.Hoy, "A multidisciplinary analysis of the nature, meaning, and measurement of trust", Review of Educational Research, Vol. 70, No. 4, pp. 547-593, 2000.

[46] Y.Van den Berg, "The relationship between organisational trust and quality of work life", (Doctoral dissertation), 2011.

[47] E.M.Whitener, "The impact of human resource activities on employee trust", Human Resource Management Review, Vol. 7, No. 4, pp. 389-404, 1997. 